\title{
EQUILIBRIUM
}

Quarterly Journal of Economics and Economic Policy

VOLUME 7 ISSUE 1, 2012

ISSN 1689-765X

\author{
Izabela Bednarska-Wnuk* \\ University of Lodz, Poland
}

\section{Flexibility of Human Resources in Creating Company's Positive Potential}

\section{JEL Classification Codes: $J 24$}

Keywords: flexibility, human resources, company's positive potential

\begin{abstract}
New concepts are more and more frequently applied in improving human resources management. It is the result of dynamic changes in the environment, as well as the necessity of searching for the 'golden mean' of managing a company. One of such means in Positive Organizational Scholarship, originating from positive psychology. Its focal points are human beings and their mental well-being, as well as evoking positive emotions in a workplace. The aim of the article is presenting Positive Organizational Scholarship and describing human resources in terms of flexibility as the primary criterion for creating a company's positive potential. The author, basing on theoretical arguments concludes that it is the flexibility that allows employees to adjust to the current conditions of their environment.
\end{abstract}

\section{INTRODUCTION}

At present, a company's resources are analyzed in order to find a way for it to succeed. In the context of a company's 'survival', development and its routine functioning it is important to react to processes of transformation

(C) Copyright Nicolaus Copernicus University Press

Date of Submission: June 21, 2011; date of acceptance: October 16, 2011

*Contact: e-mail: iwnuk@uni.lodz.pl, Uniwersytet Łódzki, Wydział Zarządzania, Katedra Zarządzania, ul. Matejki 22/26, 90-237 Łódź, Poland 
and, in the aspect of gaining a competitive advantage, to use its potential accordingly. The functioning of a company in the changing conditions requires a particular kind of flexibility, based primarily on human resources. Thus, human resources is considered to be an important asset, as one capable of creating new things (Juchnowicz, Wojtczuk-Turek 2007, p. 52). It is a consequence of the fact that human resources is a carrier of organizational values, which are among a company's strategic aspects, determining its potential. It is also more and more frequently becoming the focus of analysis by different sciences, at the same time contributing to the emergence of new concepts in terms of organizational behavior types. One of such concepts is Positive Organizational Scholarship, which despite many emerging trends in management, such as High Involvement Work Practices/System (HIWP), gains in popularity. It refers to positive psychology and is concentrated on employees' positive mental state and emotions while functioning in a workplace. Its essence is giving meaning to professional work and getting rid of all organizational pathologies. As the requirements from an employee and his or her position in a company' hierarchy are subject to constant transformations, it seems reasonable to consider flexibility indispensable in the context of human resources. Thus, in this paper, the problem of flexibility is presented from the point of view of a human being as a company's special element, contributing to the creation of its positive potential, as well as to its human resources.

The aim of the article is to present the concept of positive Organizational Scholarship and presenting human resources in the context of flexibility as the primary criterion in creating a company's positive potential, especially since it is the feature which allows employees to adjust to the current conditions in their working environment.

\section{COMPANY'S POSITIVE POTENTIAL-ITS ESSENCE AND SIGNIFICANCE FOR A COMPANY'S DEVELOPMENT}

The actions connected with a company's potential are more and more frequently emphasized in literature. However, it is the new approach towards the processes and phenomena which take place within organizations that gains most significance. The rules have been presented by K.S. Cameron, J.E. Dutton and R.E. Quinn in their book Positive Organizational Scholarship- Foundations of New Discipline as a new trend in the study of company management and managing human resources in particular. Their point of interest is an organization of any kind. The abovementioned authors, however, consider an organization in terms of its positive features, which means 
an attempt to define and understand what is good about it. Their attention is focused primarily on: leadership, processes, organizational structure and culture, the methods used, motivational systems and effectiveness (Zymonik 2007, p. 10). It is thus a human being and his intellectual resources which are the focal point of Positive Organizational Scholarship. It is due to the fact that the concept studied refers back to positive psychology of Martin Seligman, who claimed the importance of a human's well-being (Seligman 2005, pp. 186-214). The well-being at a workplace is interpreted as a balance of emotions felt while working and with reference to work, which is positive and the workers are happy with their work, considering it worthy (Czerw, Babiak 2010, p. 46). Thus, POS concentrates on positive emotions, rejecting all organizational pathologies and emphasizing the employees strong and good sides. The foundations of empirical studies are aimed at achieving perfection, without any negative phenomena which might appear within an organization (Kaiser, Muller-Seitz, Ringlstetter 2007, p. 173). Thus, positive psychology creates such competences which are meant to provide protection against those negative phenomena. They are, among others: optimism, hope, courage, ability to build positive relations, kindness, work ethic, honesty and persistence in reaching one's goals. They are resources which are meant, on one hand, to prevent lack of motivation, professional burning-out and mental disorders, and on the other hand, give energy to positive actions, social utility and life and job satisfaction (Czerw 2010, p. 8).

A company's positive potential (Positive Organizational Scholarship) is also interpreted as 'such states, levels and configurations of a company's resources, which stimulate positive organizational culture, positive atmosphere and facilitate pro-development behaviors of employees' (Stankiewicz 2010, p. 291). The definition emphasizes resource-based approach, in which some particular assets serve as factors of a company's positive potential. The assets are: material resources, strategy and structure of an organization, factors connected with human resources management, authority and democracy of supervision, innovation, integration with the company and leadership (Stankiewicz 2010, p. 291). The binding element here is flexibility.

Positive Organizational Scholarship presents that approach to problemsolving In an organization. It leads to development of employees, supporting their pursuit of perfection and cultivating extraordinary achievements at the level of a company and an individual. Thus, it emphasizes such features of an employee as creativity, optimism or emotional intelligence. A company's positive potential concentrates also on positive results, processes of organization and the people it employs, which is a key feature in under- 
standing why some organizations enjoy greater employee and customer loyalty, and achieve greater effects 9 (Czerw 2010, p. 39).

A company's positive potential can also be helpful in introducing changes in situation when there is resistance against it. First of all, one should turn to OD consultant and determine the dysfunctional aspect within an organization and take into account organizational values of the organization, motivational system and the limitations one can encounter. It is also important to clearly define those limitations which might be useful in problem-solving in order to stimulate positive changes (Bright 2009, p. 4). Thus, while breaking the resistance towards changes in a company which is characterized by positive potential, the managers will use the techniques which involve creating positive motivation and emotions. The managers should also aim at effective communication and stimulate the employees to further development, by nurturing their talents at the same time.

The research done while studying a company's positive potential concluding the findings by A. Caza and K. S. Cameron, as well the results of empirical studies by other authors, concern first of all individual and social virtues, leadership, positive relations, organizational virtues, efficiency and human resources (job satisfaction, organizational involvement, motivation) (Caza, Cameron 2008, pp. 9-14). And so, there are a number of studies (Bono, Ilies 2006) concerning the role of positive phenomena in explaining leadership. It turned out that leaders who show more positive emotions stimulate the same emotions of their employees and have more influence upon their emotional state (Bono, Ilies 2006, p. 321). In addition, in another study (Verbeke et all 2004, pp. 386-402) carried out among Dutch workers in charge of sales it was noticed that in situations when such values as motivation, creativity and altruism are dominant the sales went up and thus higher efficiency was achieved.

Thus, positive organizational potential concentrates on the company workers' positive behaviors and positive emotions. It seems at the same time that it would be ideal to approach both positive and negative phenomena occurring within an organization. However, it turned out that in some conditions positive phenomena may result in unwanted outcomes. Similarly, the benefits from positive behaviors may be dependent upon the presence of other organizational behaviors (Caza, Cameron 2008, pp. 15-16). It is an individual who plays a crucial role in this context, as the creator of those values which might influence the company's positive potential. It seems that at present the element which determines the essence of a workers role within an organization is, apart from creativity and entrepreneurship the flexibility of human resources (Błaszczyk 2004, pp. 57-68). 


\section{FLEXIILITY-PRIMARY ATTRIBUTE OF A CONTEMPORARY ENTERPRISE}

Constant changes in the organization's environment cause that it has to be flexible, which means that it has to be able to adapt to the current conditions. It must be noted, however, that there are many definitions of the term in literature, emphasizing its various distinguishable features and characteristics. An extensive analysis of the term is presented by R. Krupski, who compares different definitions of flexibility (Osbert-Pociecha 2008, pp. 1517). Special significance is given to the actions which stimulate positive behaviors of employees. They refer and are analyzed in view of (WojtczukTurek 2007, pp. 56-66):

- abilities and features- moving to behavioral dimension on one hand, and to the dimension of potentiality - pre-disposition to taking particular actions on the other.

- cognitive processes - described both in reference to elementary processes (perception, attention) and to the more complex ones (thinking, logical reasoning, making decisions).

- emotional and motivational processes - taking actions due to motives which are given the status of internal (for example needs) or external (for example prizes).

- processes connected with social functioning - a flexible individual is more competent in the interpersonal context.

Openness to the surrounding world and fast reactions to signals from it is also one of the main factors essential for success according to all contemporary concepts of management. According to B. Ziębicki, it can appear in various contexts depending on the concept. For example, in the case of virtual and network management flexibility involves the search for possibilities for the company to adapt to the environment by creating partner relations and making use of spatially dispersed competences and resources (Ziębicki 2020, p. 390). In reference to company's positive potential, on the other hand, flexibility is connected with creating positive processes and states in an organization and adapting them to its present state and resources.

Making an organization more flexible is aimed primarily at minimizing negative consequences, which might be brought about by changes occurring in an organization, or facilitating positive phenomena. The basic tools of flexibility are: redundancy of resources (surplus of resources allows for relatively quick reaction in situations which are hard to predict, identified as opportunities), diversification of actions and (or) resources (they create relatively greater potential threats, thus enhancing the range and extent of adapting to the changes in the environment and the organization as such) 
and monitoring (which concerns not only recording the past or the present, but also predicting the future) (Krupski 2005, pp. 26-27). J.E. Rydeen, on the other hand, includes: expandability (ability to grow), rationality (adapting to changes), versatility (offering many functions) and plasticity (it can be shaped at will) (Raydeen 2004, p. 52). The features gain special significance in the context of treating flexibility as contemporary worker's desirable feature (Wojtczuk-Turek 2007, p. 66). It thus seems that an employee's flexibility should be perceived as a standard disposition and be a connection with a situational context. Such perception of flexibility is important especially since in psychological terms it can be viewed upon from the point of view of ability and skills, as well as giving it the status of potentiality - pre-disposition to particular actions (Wojtczuk-Turek 2007, p. 57). In this context, flexibility becomes an element of human resources, which can play a crucial part in creating a company's positive organizational potential.

\section{FLEXIBILITY OF HUMAN RESOURCE AND THE COMPANY'S POSITIVE POTENTIAL}

The issue of flexibility is very popular at present, especially since it is of crucial importance in the context of organizational behaviors and describing a company's assets. It is also believed that among many available resources of an organization it is the human resources that determine its potential (Piórkowska-Wojciechowska 2008, p. 94). In the process of a company shaping its positive potential, it should focus primarily on acquiring, implementing, developing and preserving its most crucial assets (Colbert 2004, pp. 341-358), which are human resources, determining a company's worth and its competitive position.

At present, however, the concept of treating people as one of the assets is being abandoned, with higher status being given to human resources (Juchnowicz 2007, p.14), which puts special emphasis on the employees' innovativeness and creativity. It can also be justified by the challenges of the economy based on knowledge. Although there are many definitions of human resources, it seems that in terms of this study the most appropriate one is provided by S. Marciniak in the individual aspect, according to whom it is 'a concealed pool of knowledge, qualifications, skills and abilities, completed with the attitude of willingness to develop one's potential for creating economical values' (Marciniak 2000, p. 155). It is a definition which includes the elements most frequently referred to in the definitions of intellectual capital, such as knowledge, skills, abilities, creating new values or worker's adaptability to changes in the environment. Since flexibility is 
the criterion for an organization's effectiveness (Ziębicki 2010, pp. 387$395)$, then it both effectively influences the results which create socioeconomic conditions, with those in turn determining human resources, work potential and the workers' ability to adapt to changes in the environment (Szałkowski 2006, p. 333). According to Szałkowski, it is the adaptability that is especially crucial, since it is linked to developing the potential possessed, and the consequence of that connection is the improvement in the work potential of the individuals functioning within an organization. It is primarily aimed at: developing competences useful to the company, systematic gain in knowledge and professional skills, as well as improving the behavior and motivation of workers essential for the achievement of the company's goals (Szałkowski 2006, p. 333).

In the context of this analysis a question arises: how can flexibility of human resources raise a company's potential, based on positive states and emotions? Such question requires a double-track answer. First of all, the development of a positive organizational potential is predominantly a change of the existing system of norms and values. It is in this domain that an employee's adaptation to changes is required. Secondly, the changes must be correlated with individual needs, as well as the needs of the environment and the company which functions in it. In such situation Interactive Model of Behavioral Flexibility is implemented, in order to explain the appearance of particular behaviors in an organization. The behaviors included there are creative, regulative and adaptative ones. Thus, according to the model, the types of workers' behavior as well as their effectiveness are closely linked to situational context (Wojtczuk-Turek 2007, pp. 67-68). In the case of creating positive potential of an organization, a worker who is 'equipped' with flexibility may engage in the following behaviors:

- adaptative - for example, if a company wants to prevent lack of motivation of professional burn-out, employees can be taught to build positive relations of cope with stress at work;

- creative - connected with changes being implemented or initiated by employees who introduce positive emotions, states and processes into an organization as a part of POS;

- regulative - just like it was in the case of creative types of behavior, it involves changes being implemented and initiated by employees, with the only difference being the lack of acceptance for them in their first stages.

Making use of the flexibility of human resources in building up an organization's positive potential is manifested also by means of reinforcing, preserving and modifying employees' behavior. We must not forget that flexibility of human resources is meant to emphasize an employee's role as a special element of an organization which develops positive potential. The 
flexibility is supposed to be shown in an employee's attitudes, knowledge and skills. The result is that a worker with a flexible approach to his work develops the desired organizational climate. It is thus an answer to the company's needs concerning particular desirable competences. An employee can also raise his qualifications by participating in various trainings.

An organization which pays attention to its employees' positive emotions enjoys less fluctuation, greater creativity and worker loyalty, as well as job satisfaction. The organization is thus aimed at improving its employees' well-being, basing on the belief that such actions result in better organizational effectiveness. There is even an issue of managing satisfied workers, which brings about particular organizational and economic benefits (Czerw 2010, p. 40).

\section{CONCLUSIONS}

The analysis presented was aimed at describing human resources as a company's most essential asset, at the same time pointing to the aspect of flexibility in building up an organization's positive potential. A company's human resources should thus be characterized by flexibility, which means the ability to adapt to particular conditions. The analysis concerning POS allows us to add that in the Western countries its dynamic development can be noticed, especially in view of empirical studies carried out. In Poland, on the other hand, the research is still scarce, although conferences concerning a company's positive potential are held more and more frequently. It also seems that further studies should be focused on finding answers to the following questions: which factors (apart from flexibility of human resources) can determine the development of positive potential of an organization, who is responsible for the development and does it have a chance of being implemented in Polish organizations, and if yes, would they be economic or non-profit organizations? Those and other questions should become an inspiration for other researchers, especially in terms of devising an 'optimum' organization model, free of negative emotions, processes, states and pathologies of any kind.

\section{LITERATURE}

Błaszczyk W. (2004), Kreatywność i przedsiębiorczość jako cechy wspótczesnego menedżera, [in:] T. Listwan (ed.), Sukces w zarzqdzaniu kadrami. Perspektywa globalna i lokalna, Prace Naukowe Akademii Ekonomicznej we Wrocławiu nr 1032, Wrocław. 
Bono J. E., Ilies R. (2006), Charisma, positive emotion and mood contagio, "Leadership Quarterly", Vol. 17.

Bright D. S. (2009), Appreciative Inquiry and Positive Organizational Scholarship, A Philosophy of Practice for Turbulent Timer, "Old Practitioner", Vol. 41, No 3.

Caza A., Cameron K. S. (2008), Positive Organization Scholarship: What does it achieve? http://www.iese.edu/en/files/6_40619.pdf (5.012011).

Colbert, B. A. (2004), The complex resource-based view: implications for theory and practice in strategic human resource management, "Academy of Management Review", vol. 29, no. 3 after: R. Kazlauskaite, I. Bučiūniene (2008), The Role of Human Resources and Their Management in the Establishment of Sustainable Competitive Advantage, "Engineering economics", No. 5 (60).

Czerw A. (2010), Zarzqdzanie zadowolonymi ludźmi, „Personel i Zarządzanie”, nr 3.

Czerw A, Babiak J. (2010), Transformacyjny styl kierowania w tworzeniu pozytywnej organizacji, ,Zarządzanie Zasobami Ludzkimi”, nr 6

Juchnowicz M., Wojtczuk-Turek A. (2007), Elastyczne zarzqdzanie kapitatem ludzkim jako paradygmat nowoczesnej gospodarki, [in:] M. Juchnowicz (red.), Elastyczne zarzqdzanie kapitatem ludzkim w organizacji wiedzy, Difin, Warszawa.

Kaiser S., Muller-Seitz G., Ringlstetter M. (2007), Die Wende der Organisationsforschung zum Guten? "Zeitschrift Führung und Organisation", Nr. 3.

Krupski R. (2005), Zarzadzanie przedsiębiorstwem w turbulentnym otoczeniu. Ku superelastycznej organizacji, Polskie Wydawnictwo Ekonomiczne, Warszawa.

Marciniak S. (2000), Innowacje i rozwój gospodarczy, Wydawnictwo Kolegium Nauk Społecznych i Administracji Politechniki Warszawskiej, Warszawa.

Osbert-Pociecha G. (2008), Elementy teorii elastyczności organizacji, [in:] R. Krupski (ed.), Elastyczność organizacji, Wydawnictwo Uniwersytetu Ekonomicznego we Wrocławiu, Wrocław.

Piórkowska-Wojciechowska K. (2008), Elastyczność zasobów ludzkich, [in:] R. Krupski (ed.), Elastyczność organizacji, Wydawnictwo Uniwersytetu Ekonomicznego we Wrocławiu, Wrocław.

Rydeen J.E. (2004), What is flexibility?, “American School \& University”, vol. 76, issue 9.

Stankiewicz M. J. (2010), Pozytywny potencjat organizacji jako kluczowy czynnik rozwoju przedsiębiorstwa, [in:] H. Jagoda, J. Lichtarski (ed.), Kierunki i dylematy rozwoju nauki i praktyki zarzadzania przedsiębiorstwem, Wydawnictwo Uniwersytetu Ekonomicznego we Wrocławiu, Wrocław.

Szałkowski A (2006), Efektywność jako kryterium rozwoju potencjału pracy, [in:] A. Stabryła (red.), Doskonalenie systemów zarzadzania w spoteczeństwie informacyjnym, t. 2, Wydawnictwo Akademii Ekonomicznej w Krakowie, Kraków.

Verbeke W., Belschak F., Bagozzi R.P. (2004), The adaptive consequences of pride in personal selling, "Academy of Marketing Science Journa", Vol. 32, No 4 after: Caza A., Cameron K.S. (2008), Positive Organization Scholarship: What does it achieve?, http://www.iese.edu /en/files/6_406 19.pdf (5.01.2011). 
Ziębicki B. (2010), Elastyczność jako kryterium efektywności organizacyjnej, [in:] W. Błaszczyk, I. Bednarska-Wnuk, P. Kuźbik (ed.), Nurt metodologiczny w naukach o zarzadzaniu, Wydawnictwo Uniwersytetu Łódzkiego, Łódź.

Zymonik Z. (2007), Positive Organizational Scholarship (POS) nowym trendem w naukach o zarzadzaniu, „Problemy Jakości”, nr 10. 